HABITAT, 31 (2), 2020, 48-54

DOI: 10.21776/ub.habitat.2020.031.2.6

\title{
Measuring E-Service Quality In Agriculture Company
}

\author{
Dian Retno Intan ${ }^{1 *}$, Budi Setiawan ${ }^{2}$, Agustina Shinta ${ }^{2}$ \\ ${ }^{1}$ Postgraduate Magister of Agribusiness, Faculty of Agriculture, University of Brawijaya \\ ${ }^{2}$ Department of Agribusiness, Faculty of Agriculture, University of Brawijaya
}

Received: 27 November 2018; Revised: 6 July 2020; Accepted: 17 July 2020

\begin{abstract}
Nowadays, E-Service Quality is known to be one of the keys that determines e-commerce success. Delivering quality in service becomes a very important strategy for marketers who try to offer different services in order to be able to compete with other companies. This study aimed to measure and evaluate the e-service quality of a agriculture company in Malang through three dimensions of e-service quality by Collier and Bienstock (2009), which were the dimensions of process, outcome and recovery. Data collection was carried out using an online survey, where the data collected was 41. Data were analyzed using confirmatory factor analysis. The results showed that the recovery dimension was the most influential dimension on consumer evaluation of e-service quality. This study gave recommendation to online shop managers to allocate more resources to the recovery dimension to improve consumer perceptions of e-service quality.
\end{abstract}

Keywords: e-service; quality; confirmatory factor analysis

\section{How to Cite:}

Intan, D. R., Setiawan, B., \& Shinta, A. (2020). Measuring E - Service Quality In Agriculture Company. Habitat, 31(2), 48-54. https://doi.org/10.21776/ub.habitat.2020.031.2.6

\section{Introduction}

Indonesia is one of the countries with the largest internet users in the world. Based on data from the Ministry of Communication and Information (2018) the number of internet users in 2017 has reached 143.26 million people or equivalent to 54.68 percent of the total population of Indonesia. This number shows an increase of 10.56 million people from the survey results in 2016, amounting to 132.7 million people. This large number shows the huge market opportunity for e-commerce owners. This great opportunity will naturally be accompanied by intense competition between e-commerce.

In the early days of e-commerce development, web presence and low prices were believed to be the drivers of the success of Zeithaml et. al., (2002). But as there is much research on e-commerce, Lee and Lin (2005) conclude that the main determinants of success and failure of e-commerce based companies are not only in the presence of web sites and low prices, but also in e-service quality. .

*Corresponding Author

E-mail: dianretnointan@gmail.com

Telp: +62-853-72160911
The e-commerce strategy which initially focused on web presence and low prices has now shifted to focus on e-service quality. This is because the web presence and low prices are not able to replace the quality of service problems that commonly occur, such as: transactions that cannot be completed by consumers, products are not sent on time or even not sent at all, e-mails that are not reply, and information which is not accessible. This is the reason why e-service quality strategy becomes a different strategy. Companies need to shift the focus of e-commerce to e-services (both before, during and after transactions) to encourage repeat purchases and build customer loyalty.

Service quality involves a comparison between expectations and performance, as explained by Lewis and Booms (1983) in Parasuraman et. al (1985) that service quality is a measure of how well the service level matches customer expectations. Delivering quality service means consistent with customer expectations. This is an important strategy for marketers to differentiate their service offerings by setting value and satisfying customer needs.

The main area of concern for e-marketing is understanding the role of customer service in internet transactions. This is because there is no direct contact between persons, marketers are 
tasked with building relationships with customers they have never seen and who have never seen it (Dobie et. Al, 2001). Gounaris et.al (2010) added that companies with good service quality produce greater profits because they are able to create customer loyalty.

Given the importance of evaluations of consumers for service quality will raise the issue of what dimensions most consumers consider in evaluating service quality. Research on e-service quality has actually been done a lot abroad, but in Indonesia it is still fairly new, especially the field that was made the object of this research, namely agriculture. In contrast to manufactured products, agricultural products are perishable products, each product has its own specifications, both size, color, level of maturity, and others. In addition, the assessment of e-service quality by using a second order construct is still rarely done so this research is deemed necessary.

Conceptual models in this study are shown in Figure 1. This model displays the measurement of the second order construct of eservice quality through the dimensions of process, outcome, and recovery. The definition of e-service quality was first defined by Zeithaml, Parasuraman, and Malhotra (2002) as the extent to which Web sites facilitate shopping, purchasing, and shipping of products and services that are efficient and effective.

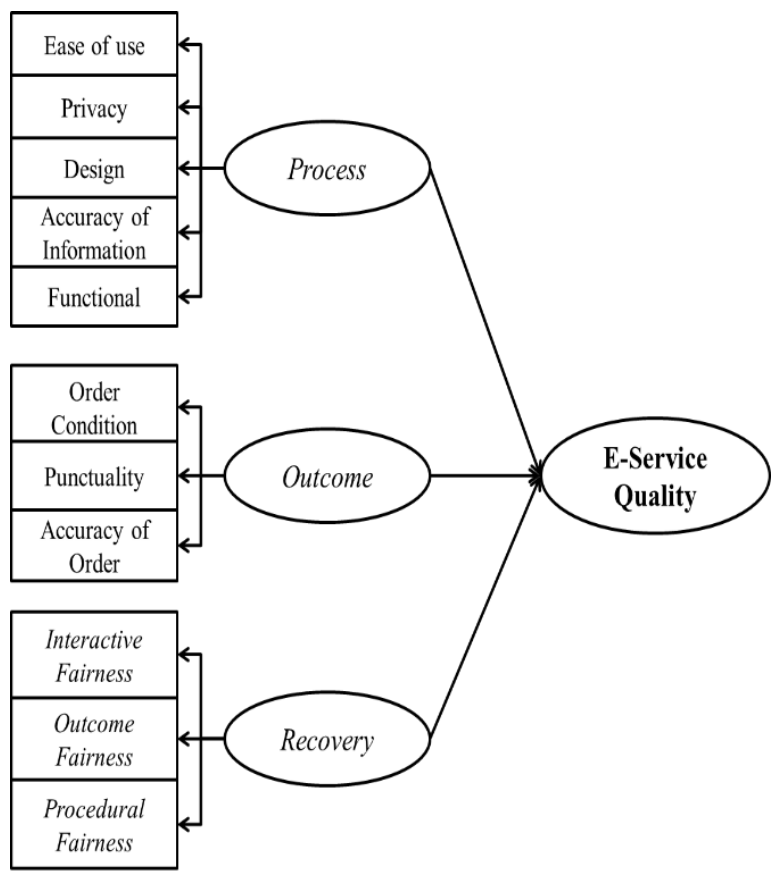

Figure 1. Conceptual Model

Collier and Bienstok (2006) in their research measured the perceived e-service quality using 3 dimensions because it considers the unique characteristics of service quality perception in online settings, namely the process dimension (based on interactive processes that take place online), results (results of how the product or service delivered), and recovery (the way service failures are handled), to increase understanding of how customers assess the quality of e-service.

The dimensions of the process or interactive qualities that occur between consumers and Web sites are represented by five dimensions: privacy, design, accuracy of information, ease of use, and functionality. A privacy construct means that the company does not share consumer information with third parties, including sensitive information between consumers and the company. Design is a visual display and application that can be seen or heard from a site. The use of color, animation, images, text, format, and sound play an important role in assessing the quality of web and applications. In addition, the accuracy of the information and detailed explanation also affects satisfaction and intention to review and repurchase. Ease of use is the ability of customers to find information or make transactions with the least amount of effort (making transactions with the least number of "clicks"). Ease of use also includes an effective search engine, the ability to easily change or cancel orders, and the ability to inform customers of missing information. The functionality includes fast page loading, non-clogged links, and payment options. Function also refers to the ability to appeal to a universal audience with multilingual translation and access and disability services.

Just like the process dimension, the yield dimension also has other dimensions for measurement, namely the timeliness of the order, the accuracy of the order, and the condition of the order. Timeliness of order refers to the receipt of service in the expected amount of time. The accuracy of the order is to process an online order according to customer specifications, which includes the place of receipt, quantity, and price agreed upon service. Order conditions refer to products that are free from damage and spoilage. Order conditions also refer to how well the product specifications are according to customer requirements. The outcome dimension is what the customer leaves at the end of the transaction and plays a very influential role in evaluating overall 
service quality. The results of a service are the main reason customers go to a website.

The recovery dimension of e-service has three other dimensions, namely interactive fairness, procedural fairness, and outcome fairness. Interactive fairness in the online context refers to the ability of customers to find and interact with technology support on the Web site and how company employees treat customers. Interactive fairness from a technology support perspective includes online tutorials, questions and answers, and e-mail addresses where customers can voice problems or concerns. Procedural fairness refers to policies, procedures and responsiveness in the complaints process. Online procedural fairness refers to the company's return policy, buyer's rights in case of fraudulent costs, and how quickly a problem can be resolved. Outcome fairness includes compensation issues, future free services, or apologies. Outcome fairness in an online context can resend products that fail to reach customers. If the company has a service failure, it must be prepared to address the problem to customer satisfaction.

In the competition, the company will try to increase consumer demand for goods and or services offered, so producers need to understand well what are the elements of the consumer shopping experience that are very important for customer satisfaction and potential customers. This research aims to study what factors are considered by consumers in evaluating e-service quality and provide a more comprehensive understanding of relevant phenomena to academics and practitioners.

\section{Research Methodology}

The place of research was chosen based on the phenomenon or problem in accordance with the research objectives. The study was conducted at an online shop in Malang which provided vegetables. This online shop was established in 2017. Sampling uses non-probability sampling with convenience sampling techniques. Convenient sampling is a type of non-probability sampling method where the sample is taken from a group of people who are easy to contact or reach (Wrenn et al., 2002). The convenience sampling method was chosen for data collection based on prior research considerations (Gummerus, 2004; Carlson and O'Cass, 2010) investigating e-service quality and website effectiveness has shown that the convenience sampling approach is an efficient and acceptable sampling method for adopting.

Data is collected by using online questionnaires and observations. Data collection uses a questionnaire with a number of closed questions and distributed online through a website. The answer to the question will be a Likert Scale with 5 scales in the category of strongly disagree to strongly agree $(1-5)$. The data obtained is then seen its validity and reliability before being analyzed using PLS (Partial Least Square) to determine the relationship between constructs.

This study uses PLS as an analysis tool with several considerations, including PLS not making assumptions about distribution, being able to estimate complex models when using small sample sizes and not requiring interval scale measurements. Furthermore, PLS is not inhibited by collinearity between manifest variables. Chin (1998) states that the minimum sample size required for covariance-based techniques (eg AMOS and LISREL) is 200, while for PLS the minimum sample size ranges from 30 to 100 . Therefore, the sample size from the current study reaches a benchmark for using PLS.

\section{Results and Discussions}

\subsection{Evaluation of Measurement Model}

Table 1. Result of Convergent validity Test $1^{\text {st }}$ order

\begin{tabular}{cccccc}
\hline Variables & Dimension & Indicator & $\begin{array}{c}\text { Loading } \\
\text { Factor }\end{array}$ & SE & $\begin{array}{c}\text { P } \\
\text { value }\end{array}$ \\
& & Feasibility & 0.903 & 0.903 & $<0.001$ \\
\hline \multirow{3}{*}{ Perceived E-Service Quality } & \multirow{2}{*}{ Process } & Privacy & 0.928 & 0.928 & $<0.001$ \\
\cline { 3 - 6 } & & Design & 0.952 & 0.952 & $<0.001$ \\
\cline { 3 - 6 } & & Accuracy of Information & 0.948 & 0.948 & $<0.001$ \\
\cline { 2 - 6 } & & Functional & 0.919 & 0.919 & $<0.001$ \\
\hline
\end{tabular}




\begin{tabular}{cccccc}
\hline \multirow{2}{*}{ Variables } & Dimension & Indicator & $\begin{array}{c}\text { Loading } \\
\text { Factor }\end{array}$ & SE & $\begin{array}{c}\text { P } \\
\text { value }\end{array}$ \\
\cline { 3 - 6 } & \multirow{3}{*}{ Outcomerceived E-Service Quality } & Order Condition & 0.956 & 0.956 & $<0.001$ \\
\cline { 3 - 6 } & & Punctuality & 0.908 & 0.908 & $<0.001$ \\
\cline { 3 - 6 } & \multirow{3}{*}{ Recovery } & Accuracy of Order & 0.931 & 0.931 & $<0.001$ \\
\cline { 3 - 6 } & & Interactive Fairness & 0.945 & 0.945 & $<0.001$ \\
\cline { 3 - 6 } & & Outcome Fairness & 0.970 & 0.970 & $<0.001$ \\
\cline { 3 - 6 } & & Procedural Fairness & 0.969 & 0.969 & $<0.001$ \\
\hline
\end{tabular}

The validity testing is done by convergent validity and discriminant validity analysis, while the reliability test is seen from the composite reliability and Cronbach's alpha. Table 1 . Shows the results of the Convergent validity 1st order test where it is known that all indicators in the study are valid, as stated by Chin (1998) that the rule of thumb for convergent validity is loading > 0.7. In addition to convergent validity, indicator validity can also be measured using discriminant validity, where the test results show that each indicator is valid in measuring their respective variables.

Table 2. Result of Validity Test $2^{\text {nd }}$ Order Formative Model

\begin{tabular}{lllll}
\hline \multicolumn{1}{c}{ Variable } & Dimension Weight & SE & P value \\
\hline Perceived & Process & 0.348 & 0.135 & 0.007 \\
\cline { 2 - 5 } E-Service & Outcome & 0.343 & 0.135 & 0.008 \\
\cline { 2 - 5 } Quality & Recovery & 0.349 & 0.135 & 0.007 \\
\hline
\end{tabular}

In contrast to reflective indicators, formative indicators are not measured for correlation, but rather compare the weights of each indicator so that it can be determined which indicators contribute most to the construct (Table 2 ). Based on the validity test results above it is known that the value of $p$ value $<\alpha=5 \%$, so that the three dimensions in perceived e-service quality are declared valid.

Table 3. Result of Reliability Test

\begin{tabular}{lccc}
\hline Variables & Dimension & $\begin{array}{c}\text { Composite } \\
\text { Reliability }\end{array}$ & $\begin{array}{c}\text { Cronbach's } \\
\text { Alpha }\end{array}$ \\
\hline Perceived & Process & 0.970 & 0.961 \\
\cline { 2 - 4 } e-service & Outcome & 0.952 & 0.924 \\
\cline { 2 - 4 } quality & Recovery & 0.974 & 0.959 \\
\hline
\end{tabular}

Table 3 shows the composite reliability value on the process, outcome, and recovery dimensions is greater than 0.7. Thus, based on the calculation of composite reliability all indicators that measure these dimensions are declared reliable. Furthermore, the Cronbach's Alpha value on the process dimension, output and recovery, is greater than 0.6. Thus, based on
Cronbach's Alpha calculations all indicators that measure these dimensions are declared reliable.

Based on the loading factor value, out of the five indicators that measure the process dimension, namely ease, privacy, design, information accuracy, and functionality, the design indicator is the most influential indicator on consumer evaluation of the process dimension. Design decisions occur at many levels including the structure, look and feel of the entire website, the structure and individual elements that appear on a particular page, and even graphical representations and representations at the level of individual links (Hofacker, 2007). This physical design has a big impact on affective reactions and attitudes towards customers. Hofacker also posits that among the visual effects observed when a background or subtle element has a real impact on attitudes and choices. In addition, other variables such as color, structure, navigation, and links have been shown to influence the decision to explore a website. Thus, it can be concluded that consumer behavior, satisfaction and pleasure is very dependent on the design or views on the website, social media and application appearance.

Based on the loading factor value of the three indicators measuring the outcome dimensions, namely order conditions, timeliness, and order accuracy, it is known that the order condition indicator is the indicator that most influences consumer evaluations of the outcome dimensions of e-service quality. Order conditions are related to damage that can occur during order handling. If the ordered goods are damaged when received by consumers, consumers must follow the procedure in the complaint and wait for the goods to be replaced by the seller. Order conditions are even more pronounced when viewed from products sold by X's online shop that sells vegetable and fruit products. If the product is not handled properly, post-harvest damage can occur such as wounds, yellowing, and even rot. 
Hofacker et. al ,. (2007) states that in the online shop world, the results of e-service are traditionally measured, namely by comparing expectations and results received (orders received). Of course in the website or application, the online shop will display good product photos. This is what creates hope for consumers that they will get goods as they are displayed, fresh and clean. Therefore, handling products must be done carefully to create good product conditions.

The analysis shows that of the three recovery dimension indicators, namely interactive fairness, outcome fairness, and procedural fairness it is known that the outcome fairness indicator is the most influential indicator for consumers in evaluating the recovery dimensions of e-service quality. However, based on descriptive analysis of respondents, the outcome fairness indicator is not the best indicator among the other two indicators. This shows the need for an increase in the field of outcome fairness so that consumers' perceptions of the recovery dimension in e-service quality are getting better.

Outcome fairness focuses on allocating benefits and costs, regarding online shop compensation for service failures. Based on previous research, consumers do prefer compensation for the amount of resources greater than the loss received. Consumers prefer real responses to their complaints because they have paid for merchandise or because real offers are associated with sincerity (Goodwin and Ross, 1992). Consumers who receive refunds, compensation for lost time, or even free gifts will give favorable results; on the other hand, a company that refuses to compensate consumers can create unfavorable results.

\subsection{Important Dimensions in E-Service Quality Evaluation}

Figure 2 showed that based of the three dimensions measuring the e-service quality variables, it is known that the recovery dimension is the dimension with the greatest contribution in shaping the e-service quality variable. Service failure occurred when a service is not functioning or running as intended by the provider, or as expected by the customer, which results in customer dissatisfaction. Failures can occur during the service process, or may not be visible until the results of the service are received. Process failure can be described as inconvenience when an order is made or during shipping. For example, failure of the e-service process can occur when moving from one web page to another is not smooth or when navigation is difficult, when the steps involved in ordering a service are slow, full of effort, or unclear. Failure to occur can occur when the service delivered is not the same as requested, when it does not meet specifications, when the service is not sent, the service is not delivered on time, or when the product service is delivered in bad condition.

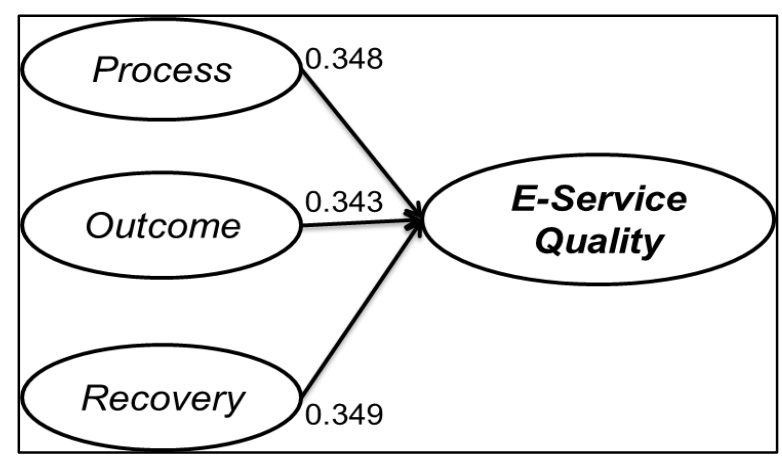

Figure 2. Loading Factor of E-Service Quality's Dimensions

The most common failures in online-based businesses are shipping problems, website problems, customer service problems, and payment problems. Smith et.al (1999) mentions that there are two types of failures that require different remedies. Process failures (from visiting the website to the actual purchase) and failure of the results (what the customer gets). When a service failure occurs, the provider must make a recovery effort. Holloway and Beatty (2003) say that recovery must be commensurate with the failure experienced, that in the failure of the process the customer experiences an emotional loss, and therefore prefers apology than money. In the failure of yields on the other hand, monetary losses and recovery must involve economic compensation.

However, a study conducted by Holloway and Beatty (2003) shows that online customers do not complain when a failure has occurred. This reduces online shop opportunities to win back customers and at the same time obtains valuable information about how to get better (Holloway and Beatty 2003). According to Gregoire, Tripp and Legoux (2009) customers who hold a grudge in an online shop will eventually break all relationships with the online shop. On the other hand Harris, Mohr and Bernhardt (2006) and Harris, et al. (2006) claim that online customers tend to blame themselves for service failures and therefore require lower 
service recovery rates to be satisfied again. Harris, Mohr and Bernhardt (2006) go on to say that companies can still make customers return, regardless of who they blame, by providing a satisfying recovery.

Previous research has found evidence that complainers who are satisfied with recovery responses have higher repurchase intentions than those who are satisfied and not complaining (Gilly, 1987 in Spreng, 1995). Service recovery efforts may be very prominent for consumers, due to increased attention and evaluation as a result of service failures. In addition, the recovery process is likely to be the last experience consumers have with companies, which results in a recency effect. Thus, when consumers contemplate service providers for subsequent transactions, the effectiveness of service recovery efforts may have a greater influence on intention than the failure of the original service. Furthermore, ineffective service recovery efforts have the potential to increase dissatisfaction.

\section{Conclusion}

Based on the results of factor analysis, it is known that the dimension that most contributes to shaping e-service quality is the dimension of recovery. The indicator of the recovery dimension that most influences consumers in evaluating e-service quality is outcome fairness. Outcome fairness focuses on compensation for financial losses and apologies. The importance of apology shows that compensation is not only for economic costs, but also for emotional costs. Based on these results, online shop owners are expected to make more funds allocated to recovery activities. This is because recovery activities can be the last interaction with customers regardless of whether or not handling recovery services. In addition, the allocation given to the recovery dimension will ultimately increase the process and outcome dimensions.

This result also has implications for online shop owners that there is a need for provisions or guidelines in compensating consumers who experience service failures. Compensation in this case can be in the form of an apology, discounted prices, to provide product changes or free products. Some consumers may consider the procedure to submit a complaint only to pretend without any real results. Likewise, an apology without tangible results can be considered insincere. Service providers may want to offer rewards and even awards when possible, rather than relying on apologies. Therefore, to create fairness in handling service failures, online shop owners need definite guidance on handling these failures. On the other hand, this guide will also encourage consumers who have failed to make complaints to the company, and the company has the opportunity to win back consumers.

\section{Daftar Pustaka}

Carlson J. dan O'Cass A. 2010. Exploring The Relationships Between E-Service Quality, Satisfaction, Attitudes and Behaviours In Content-Driven E-Service Web Sites. Journal of Services Marketing. Vo.1 24 No. 2. Hal $112-127$.

Chin, W. 1998. The Partial Least Squares Approach for Structural Equation Modelling. in Marcoulides, G. (Ed.). Modern Methods for Business Research. Laurence Erlbaum Associates. Mahwah. NJ. Hal. 295 - 336.

Collier, J. and Bienstock, C. 2006. Measuring service quality in e-retailing. Journal of Service Research. Vol. 8 No. 3. Hal $260-$ 275.

Dobie, K., J. Grant., dan K Ready. 2001. Product Motivation and Purchasing Activity. Journal of Promotion Management. Vol 6. No 1-2. Hal $31-43$

Goodwin C dan I Ross. 1992. Consumer Responses to Service Failures : Influence of Procedural and Interactional Fairness Perceptions. Journal of Business Research. Vol 25 Hal. 149 - 163.

Gounaris, S., S. Dimitriadis., V. Statakopoulos. 2010. An Examination of The Effects of Service Quality and Satisfaction on Customers' Behavioral Intentions in EShopping. Journal of Service Marketing. Vol 24 No 2. Hal 142 - 156.

Gregoire, Y, T M Tripp, and R Legoux. (2009) "When customer love turns into lasting hate: The effects of relationship strength and time on customer revenge and avoidance." Journal of Marketing 73, no. 6: $18-32$.

Gummerus, J., Liljander, V., Pura, M., \& Riel, A. (2004). Customer loyalty to content-based web sites: the case of an online health-care service. Journal of service marketing, 18 (3), 175-186. 
Harris, K E, D Grewal, L A Mohr, and K L Bernhardt. (2006) "Consumer responses to service recovery strategies: The moderating role of online versus offline environment." Journal of Business Research 59, no. 4: 425-431.

Hofacker, C.F., Goldsmith, R.E., Bridges, E. and Swilley, E. 2007. E-Services: A Synthesis And Research Agenda. Journal of Value Chain Management. Vol. 1 No. 1/2. Hal 13 $-44$.

Holloway, B B, and S E Beatty. (2003) "Service Failure in Online Retailing : A Recovery Opportunity." Journal of Service Research 6, no. 1: 92-105.

Kominfo. 2018. Jumlah Pengguna Internet 2017 Meningkat, Kominfo Terus Lakukan Percepatan Pembangunan Broadband (Online).

https://kominfo.go.id/index.php/content/de tail/12640/siaran-pers-no-

53hmkominfo022018-tentang-jumlahpengguna-internet-2017-meningkatkominfo-terus-lakukan-percepatanpembangunan-broadband/0/siaran_pers. Diakses tanggal 26 November 2018.

Lee, G. dan Lin, H. 2005. Customer Perceptions of E-Service Quality in Online Shopping. International Journal of Retail \& Distribution Management. Vol. 33 No. 2. Hal $161-76$.

Parasuraman, A., V A Zeithaml, dan L. Berry. 1985. A Conceptual Model of Service Quality and its Implications for Future Research. Journal of Marketing. Vol 49. Hal $41-50$.

Smith, A, R Bolton, and J Wagner. (1999) "A Model of Customer Satisfaction with Service Encounters Involving Failure and Recovery." Journal of Marketing Research 36, no. 3: 356-372.

Spreng, R., Harrell, G. dan Mackoy, R. 1995. Service Recovery: Impact on Satisfaction and Intentions. Journal of Services Marketing. Vol. 9 No. 1. Hal 15 - 23.

Wrenn, B., W B Wrenn, D L Loudon, dan R E Stevens. 2002. Marketing Research : Text and Cases. New York. Best Business Book.
Zeithaml, V.A., Parasuraman, A. dan Malhotra, A. 2002. Service Quality Delivery Through Web Sites: A Critical Review of Extant Knowledge. Journal of the Academy of Marketing Science. Vol. 30 No. 4. Hal 362 -375 . 